DOI: $10.15290 /$ bsl.2018.12.16

\author{
Katarzyna Trusewicz \\ Wydział Filologiczny \\ Uniwersytet w Białymstoku \\ e-mail: katarzynatrusewicz@gmail.com \\ ORCID: 0000-0003-3982-1642
}

\title{
Herbstory/herstory w wydaniu Simony Kossak
}

\begin{abstract}
„To odtwarzanie starych miejsc - zagród, dworów jest możliwe dzięki roślinom, które w przeciwieństwie do ludzi nie porzuciły obejścia. [...] Rośliny, te związane z człowiekiem albo wysiane jego ręką, są jak resztki obecności dawnych właścicieli i gospodarzy" ${ }^{1}$.
\end{abstract}

Simona Kossak, jako profesor nauk leśnych i biolog, publikowała nie tylko artykuły naukowe, również działalność popularyzatorska stanowiła ważny element jej pracy. Opowiadania o ziołach $i$ zwierzętach. Zgodnie z natura swojego gatunk $u^{2}$, wydane po raz pierwszy w 1995 roku, stanowią próbę przekazania wiedzy przyrodniczej $\mathrm{w}$ formie wypowiedzi sytuującej się na granicy dyskursów naukowego i literackiego. Książka ta otworzyła nowy etap w życiu Simony Kossak, która po kilku latach opublikowała Sagę Puszczy Białowieskiej ${ }^{3}$, rozpoczęła kilkuletni proces nagrywania gawęd dla Polskiego Radia Białystok ${ }^{4}$ oraz zajęła się realizacją filmów przyrodniczych, docenio-

\footnotetext{
${ }^{1}$ M. Książek, Droga 816, Białystok 2015, s. 127.

2 S. Kossak, Opowiadania o ziołach i zwierzętach. Zgodnie z natura swojego gatunku, Warszawa 1995.

3 S. Kossak, Saga Puszczy Białowieskiej, Warszawa 2001. W tym samym roku oraz nakładem tego samego wydawnictwa Muza ukazało się tłumaczenie książki Simony Kossak na język angielski, The Białowieża Forest saga.

4 O gawędach Simony Kossak zob. K. Trusewicz, Ekogawędy Simony Kossak, „Białostockie Studia Literaturoznawcze" 2016, nr 9, s. 95-105.
} 
nych na festiwalach filmowych ${ }^{5}$ W swoich opowiadaniach badaczka opisuje rośliny i zwierzęta zarówno pod względem ich budowy, właściwości, miejsca występowania, jak również zwraca uwagę na ich obecność w procesach historycznych i kulturowych. Tym samym istotnym elementem Opowiadan o ziołach i zwierzętach jest refleksja nad sprawczością "braci mniejszych", która stanowi istotny element badań z zakresu humanistyki ekologicznej ${ }^{6}$.

Opowiadania o ziołach $i$ zwierzętach Simony Kossak, charakteryzujące osiemdziesiąt dwa gatunki zwierząt i roślin, zostały wznowione w roku 2017 przez Wydawnictwo Marginesy (seria $\mathrm{EKO}^{7}$ ), które zmieniło nie tylko szatę graficzną, ale również tytuł książki, na: $O$ ziołach $i$ zwierzętach ${ }^{8}$.

Zaproponowany przeze mnie neologizm "herbstory" powstał jako analogia do terminu „herstory" - ,jej historia”. Dyskusja nad kobiecą perspektywą historyczną rozpoczęła się w okresie drugiej fali feminizmu w Stanach Zjednoczonych. W 1970 roku w książce Robin Morgan Sisterhood is Power$f u l^{9}$ po raz pierwszy użyto określenia "herstory" rozumianego jako forma sprzeciwu wobec wykluczania kobiet, ich życia, czynów i wkładu w dzieje ludzkości, w przekazach historycznych ${ }^{10}$. Proponując pojęcie herbstory przyjmuję, za Kossak, że w historii świata i ludzkości przeoczony został wątek historii roślin, w tym interesujących mnie ziól, podobnie jak przez całe wieki wypierano $z$ oficjalnych narracji kobiecą perspektywę. Przyczyną tego jest oczywiście fakt, że rośliny nie formułują komunikatów werbalnych, chociaż, co stwierdzone, komunikują się oraz pozostawiają ślady w przestrzeni przyrodniczo-geograficznej. Niewątpliwie botanikę można uznać za naukę trak-

5 Film Życie żaby [2000], Nagroda Specjalna dla Najlepszego Filmu Amatorskiego Międzynarodowego Festiwalu Filmów Przyrodniczych im. Braci Wagów oraz Grand Prix na Ogólnopolskim Festiwalu Filmów Amatorskich w Bełchatowie. Zrealizowała również filmy Kamasutra [2002], Opiekun [2003] oraz Motyle [2005].

6 Zob. E. Domańska, Humanistyka ekologiczna, „Teksty Drugie” 2013, nr 1-2, s. 13-32.

7 W serii EKO ukazały się również Simony Kossak Saga Puszczy Białowieskiej [2016 oraz w 2018 w twardej oprawie] a na 2019 rok planowana jest publikacja Serce i pazur. Opowieści o uczuciach zwierząt. Warto zwrócić uwagę na niezwykłą popularność książek Simony Kossak, które wydawane są również przez białostocką Fundację Sąsiedzi: Opowieści, Białystok 2016 oraz Opowieści z Dziedzinki, Białystok 2017.

8 S. Kossak, O ziołach i zwierzętach, Warszawa 2017. Wydawnictwo nie odpowiedziało na moją prośbę o uzasadnienie zmiany tytułu. $Z$ perspektywy refleksji nad deklarowaną przez autorkę formą wypowiedzi, jaką są opowiadania, kwestia jest interesująca.

9 Zob. E. Kania, Polska zdekolonizowana? „Pamięć o kobietach” i jej wymiary, „Refleksje” 2011, nr 4, s. 51.

10 Eliza Kania zwraca uwagę, że pojęcie „herstory” cieszyło się największą popularnością w latach 70. i 80. XX wieku. Christina Hoff Sommers w książce Kto ukradł feminizm? Jak kobiety zdradzily kobiety z 1994 roku próby skoncentrowania narracji historycznej na perspektywie kobiecej uznała za sztuczne i hamujące postęp. Por. tamże. 
tującą o historii roślin. Ewa Domańska, pisząc o rozwoju współczesnej humanistyki, zwraca uwagę na zmiany w postrzeganiu zwierząt, roślin i rzeczy:

Rośliny - jak udowadnia szybko rozwijająca się neurobiologia roślin (i aktywiści ruchu na rzecz obrony godności roślin) - mogą wybierać między różnymi sposobami zachowania się, reagują na stres (np. brak wody), [...], umieją odróżnić siebie od innych, są autonomicznymi bytami (zwróćmy uwagę, że pojęcie autonomii stosowane było jedynie $\mathrm{w}$ stosunku do człowieka), a ich życie ma samoistną wartość ${ }^{11}$.

Warto zauważyć, że w najnowszej myśli humanistycznej badania z zakresu nauk ścisłych, takich jak neurobiologia czy biologia syntetyczna, okazują się nie tylko cennym źródłem informacji, ale przede wszystkim są poddawane refleksji. Wnioski z prowadzonych przez naukowców badań nad roślinami, wskazujących na ich ścisłe podobieństwo do człowieka, uzmysławiają nieuzasadnioną nadrzędność antropocentryzmu i szowinizmu gatunkowego. W naukach humanistycznych pojawiła się refleksja nad sprawczością nie-ludzkich podmiotów mających wpływ na procesy historyczne. Problem ten porusza Ewa Domańska w książce Nekros. Wprowadzenie do ontologii martwego ciała, w której redefiniuje koncepcję sprawczości, proponując relacyjne jej rozumienie. Pojmuje sprawcę jako "powodującego zdarzenia w otaczającym środowisku” i, jak dodaje, „ważny jest nie tyle sprawca/aktor i jego status, ile jego miejsce $\mathrm{w}$ sieci relacji" ${ }^{12}$. W takim rozumieniu sprawstwo staje się działaniem wielu aktorów, a więc czynników ludzkich i nie-ludzkich. Roślinę-sprawcę można zatem potraktować jako aktora w sieci relacji, mającego wpływ na otoczenie. Istotnym elementem prowadzonych przez Kossak opowieści jest kwestia wpływu roślin na życie i śmierć człowieka w dziejach historii. Badaczka zauważa, że relacja między ludźmi i roślinami (ich obecność w sieci) może mieć zarówno pozytywne, jak i negatywne skutki. Relacje między ludźmi i roślinami, które można nazwać sprawczymi relacjami między aktorami w sieci, są w istocie przedmiotem jej zainteresowania. Przykładem tego jest opowieść o Borówce czarnej:

Pewien chłop syberyjski - zielarz ludowy o nazwisku Rasputin, swą mroczną karierę rozpoczął od wyleczenia carewicza Aleksego, syna cara Mikołaja II, z czerwonki, z którą nie mogli sobie poradzić dworscy lekarze. [...] Rasputin podał carewiczowi odwar $\mathrm{z}$ owoców borówki czarnej zmieszanych z pięciornikiem ${ }^{13}$.

\footnotetext{
11 E. Domańska, Humanistyka ekologiczna, s. 29.

12 E. Domańska, Nekros. Wprowadzenie do ontologii martwego ciała, Warszawa 2017, s. 63.

13 S. Kossak, Opowiadania o ziołach i zwierzętach, s. 18.
} 
W Opowiadaniach Kossak można znaleźć inne przykłady bezpośredniego wpływu roślin na losy człowieka, a nawet całej ludzkości. W ostatnich latach pojawiło się bardzo wiele książek poruszających to zagadnienie ${ }^{14}$. Publikacją szczególnie wartą przywołania jest praca Billa Lawsa 50 roślin, które zmienity bieg historii ${ }^{15}$.

Simona Kossak, w celu przybliżenia interesujących ją gatunków, posługuje się taką formułą narracji, którą sama określa opowiadaniem. Wszystkie proponowane przez nią opowieści o ziołach zbudowane są $\mathrm{w}$ podobny sposób. Autorka przedstawia budowę anatomiczną poszczególnych gatunków, następnie podaje miejsce ich występowania, właściwości lecznicze i magiczne oraz możliwości wykorzystania przez człowieka. Istotną rolę przypisuje wyjaśnieniu imienia danego gatunku oraz przywołaniu związanych $\mathrm{z}$ nim legend.

Bogdan Owczarek w tekście Od poetyki do antropologii opowiadania proponuje rozróżnić opowiadanie jako po pierwsze „,[...] czynność przekazywania informacji, integrująca nadawcę i odbiorcę, włączając je tym samym w rytm komunikacji społecznej”, a po drugie jako „,[...] historię, czyli opowieść o zdarzeniach, przypominając znane od czasów Arystotelesa pojęcie fabuły jako celowego układu zdarzeń" ${ }^{\prime 16}$. Antropologia opowiadania wyrasta według badacza z założenia:

iż kultura w ogólności w wielu swoich fragmentach ma charakter narracyjny, że w różnych jej dziedzinach i na różnych jej poziomach można odkryć struktury narracyjne, które dotąd byliśmy skłonni przypisywać literaturze czy mitologii. $\mathrm{W}$ takim sensie antropologia opowiadania byłaby narratologią różnych praktyk kulturowych ${ }^{17}$.

14 Prace o takiej tematyce często mają charakter popularnonaukowy czy quasi naukowy: M. Borovich, Rośliny nas ocala: 15 roślin leczniczych, zdolnych puścić z torbami koncerny farmaceutyczne, przeł. K. Majkowska, Warszawa 2017; A. Nowakowska, Rośliny nas ulecza: dieta na superodporność i dtugie życie, Opypy 2018; C. Harrison, L. Gardiner, Zdumiewajace zdolności roślin, przeł. A. Kowalska, A. Jankowski, Warszawa 2018; A. Stewart, Zbrodnie roślin: chwast, który zabit matkę Abrahama Lincolna i inne botaniczne okropieństwa, przeł. D. Wójtowicz, Warszawa 2011; S. Mancuso, Rewolucyjny geniusz roślin. Jak i dlaczego rośliny zmieniq nasza przyszłość, przeł. A. Wziątek, Wrocław 2018.

15 B. Laws, 50 roślin, które zmieniły bieg historii, przeł. J.J. Malinowski, Warszawa 2016.

16 B. Owczarek, Od poetyki do antropologii opowiadania, w: Praktyki opowiadania, red. B. Owczarek, Z. Mitosek, W. Grajewski, Kraków 2001, s. 11-12.

17 Tamże, s. 18. 
Antropologia opowiadania rozróżnia zatem opowiadanie na mowę i opowieść, mówienie i działanie, komunikację i prezentację ${ }^{18}$. Fakt ten pozwala ująć Opowiadania o ziołach $i$ zwierzętach Simony Kossak jako praktykę narratologiczną, w której istotną rolę odgrywa czynność przekazywania przez autorkę informacji. W tym sensie omawiane opowiadania rozpatruję nie w kontekście teorii gatunków literackich, lecz jako formę komunikacji społecznej, której celem jest narracja przyrodnicza o ziołach.

Opowiadania o ziołach i zwierzętach Simony Kossak, które określam mianem narracji przyrodniczych, wyróżnia postawa narratora zaangażowanego oraz empatycznego wobec opisywanych gatunków. Badaczka często zastanawia się nad powodami, dla których człowiek przestał szanować takie rośliny, jakimi są zioła. Przykład stanowi opisywana przez nią Werbena ${ }^{19}$, która w starożytności „była zarówno lekiem, jak i świętością” 20, a w Rzymie „należała do «wybranych roślin na ziemi», otaczana była czcią i uważana za świętą" ${ }^{21}$. Również w średniowieczu darzono ją szacunkiem, a „[...] magia uprawiana w Niemczech przypisywała jej czarodziejską siłę i posiłkowała się nią w swych mrocznych praktykach. Następne wieki o niej zapomniały" ${ }^{22}$. Zakończenie każdego opowiadania ma bardzo subiektywny charakter, gdyż Kossak wyraża w nim własne niezadowolenie ze współczesnego stosunku człowieka do ziół. W przypadku opisu Werbeny daje czytelnikowi jasno do zrozumienia, że nie zgadza się z naukowym podejściem do zioła: „Analizy chemiczne wykazały, że zawiera substancje działające leczniczo w przypadkach migreny i anemii. Jest to zbyt skromna ocena w porównaniu ze sławą «żelaznego, świętego ziela», jakim zasłużenie cieszyła się w starożytności" ${ }^{23}$. W podobny sposób pisze o Rumianku, chcąc przywrócić jego znaczenie lecznicze i magiczne:

Dziś ten symbol dobroci i słońca, wierny towarzysz rolników, obdarzony mianem "chwastu" ginie w wolnej przyrodzie wraz z innymi dzikimi ziołami, którym mroczna bogini rodem z krainy śmierci Hel - Agrochemia odmawia prawa do życia ${ }^{24}$.

\footnotetext{
18 Tamże.

19 Zapis nazw/imion ziół dużą literą stosuję w konsekwencji rozumienia ich sprawczości za pośrednictwem bycia w sieci relacji. Simona Kossak pisze nie o nazwie gatunku, lecz o imieniu, co również ma charakter upodmiotowienia roślin i zwierząt, choć sama autorka w Opowiadaniach o ziołach i zwierzętach zapisuje imiona ziół małą literą.

20 S. Kossak, Opowiadania o ziołach i zwierzętach, s. 343.

21 Tamże.

22 Tamże, s. 344.

23 Tamże, s. 345.

24 Tamże, s. 269.
} 
Do podobnych komentarzy autorka ucieka się w książce wielokrotnie, wskazując na nieuzasadnione, według niej, odrzucenie ziół przez człowieka i sprowadzenie ich do roli chwastów. Badaczka próbuje za pomocą swoich opowiadań uzmysłowić czytelnikowi wyjątkowość otaczających go ziół. Każde z nich zawiera szereg interesujących faktów zaczerpniętych z różnych źródeł.

Autorka w omawianych opowiadaniach odwołuje się do wiedzy z zakresu botaniki, wyjaśniając budowę i właściwości roślin. Równorzędnie do botaniki traktuje wiedzę ludową, stanowiącą według niej cenne źródło wiarygodnych informacji. Wzbogaca swoją narrację, przywołując także teksty kultury, zarówno literaturę wysoką, jak i ludową, tematyzującą różne gatunki ziół. Opisując Szałwię lekarską cytuje na przykład fragment utworu Rozmowa Mistrza Polikarpa ze Śmiercią: „nie pomogą i szałwije, wszystko śmierć bez ługu zmyje" 25, Podagrycznik przedstawia jako signatura rerum, symbol wiary, ponieważ układ jego liści przypomina znak krzyża ${ }^{26}$, a w opisie Paproci powołuje się na legendę nocy świętojańskiej, cytując zaklęcie rzucane przez panny zbierające Nasięźrzał, czyli paproć wypuszczającą rocznie tylko jeden liść:

Nasięźrzele, rwę cię śmiele

Pięcią palcy, szóstą dłonią,

Niech się chłopcy za mną gonią! ${ }^{27}$.

W opowiadaniu Osika przywołuje poemat Kalewala Eliasa Lönnrota, w Olszy czarnej cytuje Króla Olch Johanna W. Goethego a w Lebiodce pospolitej posługuje się fragmentem Eneidy Wergiliusza. Zabieg ten ma na celu podkreślenie współbycia człowieka i ziół w jednej, wspólnej przestrzeni historyczno-kulturowej. Tym samym sztywny podział na naturę i kulturę, jak zauważa Anna Barcz, jest nieuzasadniony ${ }^{28}$. Wspólistnienie, a przede wszystkim współdziałanie człowieka i roślin jest istotnym problemem humanistyki ekologicznej, zainteresowanej „współbycie[m], współ-życie[m] naturo-kultury, człowieka i środowiska, bytów i istot ludzkich i nie-ludzkich" ${ }^{29}$. Bohdan Dyakowski ${ }^{30}$ - żyjący na przełomie XIX i XX wieku naukowiec i po-

25 Tamże, s. 305.

26 Zob. Tamże, s. 241.

27 Tamże, s. 239.

28 Zob. A. Barcz, Zagadnienia i problemy badawcze ekokrytyki, w: tejże, Realizm ekologiczny. Od ekokrytyki do zookrytyki w literaturze polskiej, Katowice 2016, s. 19-51.

29 E. Domańska, Humanistyka ekologiczna, s. 15.

30 Analizę biografii oraz twórczości autora przeprowadza Pola Kuleczka w monografii Bohdan Dyakowski. Monografia literackiej twórczości popularyzatora wiedzy o przyrodzie, Kraków 2000. 
pularyzator wiedzy przyrodniczej - interpretując relację między człowiekiem a roślinami i zwierzętami, także sięga do źródeł literackich, w celu podkreślenia ścisłej relacji człowieka oraz roślin i zwierząt. Dyakowski był autorem licznych książek skierowanych zarówno do dorosłych, jak i do dzieci, takich jak Z puszczy Białowieskiej31, Wąż Władka: opowiadanie ${ }^{32}$ czy, wznowione w ostatnich latach, $Z$ naszej przyrody: obrazy $z$ życia roślin i zwierząt krajowych ${ }^{33}$ oraz Nasz las i jego mieszkańcy ${ }^{34}$. Większą część dorosłego życia Dyakowski spędził w Krakowie, gdzie zmarł trzy lata przed narodzinami w tym samym mieście Simony Kossak. Trudno jednoznacznie stwierdzić, czy twórczość Dyakowskiego była znana autorce opisującej Puszczę Białowieską. Niezwykle popularna książka Nasz las i jego mieszkańcy Dyakowskiego mogła być także lekturą zainteresowanej od najmłodszych lat przyrodą Kossak ${ }^{35}$.

\section{Pamięć/miejsce}

Aleksandra Żelazińska w artykule Litenatura stwierdza, że bohaterką książek o drzewach czy innych roślinach jest „[...] przyroda w swej ożywionej postaci. Zawsze obowiązkowo «sekretna», nie dość rozpoznana, nieokiełznana" ${ }^{36}$. Opowiadaniom o ziołach $i$ zwierzętach Simony Kossak towarzyszy natomiast refleksja związana z problemem pamięci i zapominania. Zioła, według Kossak, nie tyle ukrywają przed człowiekiem pilnie strzeżonych tajemnic, lecz to człowiek sam odrzucił wiedzę przekazaną mu przez rośliny. Badaczka zauważa, że „uczeni opisali wzorami chemicznymi to, co lud znał od niepamiętnych czasów" ${ }^{37}$, zastępując wiedzę ludową wiedzą laboratoryjną. Ewa Domańska podkreśla, że jedną z cech humanistyki ekologicznej

jest krytyka nauki jako uprzywilejowanego sposobu poznania. Nauka jest w końcu jednym z wielu sposobów zdobywania i organizacji wiedzy i jak się wskazuje - wcale nie najlepszym. [...]. Na fali tej krytyki coraz większe

\footnotetext{
31 B. Dyakowski, Z puszczy Białowieskiej, Warszawa 1908.

32 B. Dyakowski, Wąż Władka: opowiadanie, Warszawa 1928.

33 B. Dyakowski, Z naszej przyrody: obrazy z życia roślin i zwierząt krajowych, Warszawa 1903, wznowienie Warszawa 2017.

34 B. Dyakowski, Nasz las i jego mieszkańcy: dla młodzieży, Warszawa 1898. W kolejnych latach książka cieszyła się ogromną popularnością i była wielokrotnie wznawiana. Ostatnio w 2016 roku, pierwszy raz od roku 1951.

$35 \mathrm{~W}$ niektórych gawędach Simony Kossak pojawiają się motywy i przykłady, które można również znaleźć w twórczości Dyakowskiego. Jest to jednak temat wymagający dalszych badań.

36 A. Żelazińska, Litenatura, „Polityka” 2017, nr 10, s. 85.

37 S. Kossak, Opowiadania o ziołach i zwierzętach, s. 18.
} 
zainteresowanie wzbudzają niektóre wiedze tubylcze, uznawane już nie tyle za przedmiot badań antropologicznych, ile za platformy dla budowania alternatywnego rozumienia podmiotu, wspólnoty, sacrum, czasu, przestrzeni, relacji z nie-ludźmi ${ }^{38}$.

Kossak wprawdzie przywołuje informacje o chemicznym składzie roślin, ustalonym na podstawie specjalistycznych badań laboratoryjnych, robi to jednak bardzo lakonicznie, często dodając, że o właściwościach roślin „odkrytych" przez naukowców medycyna ludowa wie już od bardzo dawna.

Simona Kossak odwołuje się także do publikacji z zakresu botaniki, jak Dykcyonarz roślinny Jana Krzysztofa Kluka z XVIII wieku czy książki Piera Mattioliego, który w 1944 roku wydał komentarz do zielnika Dioskoridesa, pochodzącego z I wieku. Robi to ze świadomością, że tego typu publikacje przekazywały przez wieki ogromną wiedzę na temat sposobu użytkowania ziół oraz ich magicznych właściwości. Lekturze książki Kossak towarzyszy przeświadczenie, że autorka, podejmując próbę utrwalenia wiedzy o otaczających nas roślinach, $w$ istocie podejmuje próbę przeniesienia tej wiedzy z obszaru pamięci komunikacyjnej (międzypokoleniowej) w obszar pamięci kulturowej. W taki na przykład sposób pisze o Leszczynie:

Rozwidlona gałązka leszczyny, wieszcza rózga - virga divinatoria - w dawnych czasach umożliwiała odkrycie skarbów, a do dziś służy w poszukiwaniu podziemnych cieków wodnych. Najcenniejszą zaletą leszczyny jest jednak to, że jemioła, która na niej wyrosła, umiejętnie użyta, leczy wszystkie choroby. Szkoda, że i o tym zapomniano ${ }^{39}$.

Erozja pamięci o roślinach skłoniła Kossak do napisania książki, stanowiącej swego rodzaju roślinne archiwum z wiedzą o ich historycznym wykorzystywaniu przez człowieka. Tym samym jej książka wpisuje się w projekt historii ratowniczej, której istotnym założeniem jest ratowanie przyszłości. Kossak opisuje bowiem rośliny nie tylko w celu przedstawienia ich historii, ale również aby ocalić je na przyszłość. Jednym z podstawowych założeń historii ratowniczej jest wynajdowanie zapomnianych, pominiętych śladów przeszłości, które nie zostały ujęte w wielkiej historii. Z perspektywy tak rozumianej historii ważna jest interpretacja historii lokalnej, przeprowadzana najczęściej przez przewodników turystycznych, pasjonatów historii czy ludności miejscowej ${ }^{40}$.

\footnotetext{
38 E. Domańska, Humanistyka ekologiczna, s. 23.

39 S. Kossak, Opowiadania o ziołach $i$ zwierzętach, s. 182.

40 Zob. E. Domańska, Historia ratownicza, „Teksty Drugie” 2014, nr 5, s. 12-26.
} 
Historia lokalna odgrywa istotną rolę w Opowiadaniach o ziołach $i$ zwierzętach Simony Kossak, dla której centrum świata, a zarazem punktem odniesienia, była Puszcza Białowieska. Refleksja nad pamięcią lokalną łączy się zawsze z kategorią miejsca i właśnie autorka pokazuje, w jaki sposób rośliny mogą stanowić miejsca pamięci: „Skupiska bzów spotykane w lasach środkowych Niemiec dziś jeszcze wskazują miejsca osiedli Słowian Połabskich - osiedli nieistniejących od wielu stuleci" ${ }^{41}$. Tym, co pozostało po grupie Słowian, są rośliny, które dla czujnego obserwatora przestrzeni stanowią znak historycznej działalności człowieka. Podobną refleksję znajdujemy w reportażu poetyckim Michała Książka Droga 816. Tytułowa droga 816, potocznie nazywana Nadbużanką, ciągnie się wzdłuż granicy polsko-białoruskiej oraz polsko-ukraińskiej, którą stanowi rzeka Bug. Książek, z wykształcenia kulturoznawca i ornitolog, w trakcie swojej podróży również zauważa ślady dawnej obecności człowieka w opuszczonych miejscach, czego świadectwem jest charakterystyczna roślinność, nieodpowiadająca charakterowi krajobrazu. Są to tak zwane rośliny synantropijne, czyli:

rośliny towarzyszące człowiekowi. Wyrastają w pobliżu ludzkich osiedli i budowli, na poboczach dróg, śmietniskach i terenach silnie zdegradowanych (czyli na siedliskach ruderalnych). Rosną na terenach o charakterze antropogenicznym tj. o charakterze nadanym $w$ znacznym stopniu przez człowieka - np. na terenach uprawnych. Wkraczają też na tereny poddane mniejszemu lub większemu (niekoniecznie świadomemu) oddziaływaniu człowieka - czyli poddane antropopresji ${ }^{42}$.

O takich roślinach pisze również Kossak: „Tę pospolitą szarozieloną roślinę [Cykoria podróżnik - dop. K.T.], jakby przykurzoną pyłem dróg w pobliżu których rośnie, można napotkać też na nasypach i stacjach kolejowych, na ugorach i miedzach, przy płotach, śmietnikach i na gruzowiskach" ${ }^{43}$. Do takiej grupy roślin należy także Brzoza, której „lekkie nasiona przenoszone przez wiatr przyjmują się na najgorszych siedliskach piaskach, nieużytkach, odłogach i zrębach" ${ }^{44}$. Kossak przedstawia również rośliny towarzyszące człowiekowi: Pokrzywa ,jest więc wierną towarzyszką człowieka" 45, a Szałwia lekarska wykazuje się „poczciwością w służeniu czło-

41 S. Kossak, Opowiadania o ziołach i zwierzętach, s. 11.

42 Zob. Hasło „rośliny synantropijne”, http://www.atlas-roslin.pl/rosliny-synantropijne.htm [dostęp 16.01.2017].

43 S. Kossak, Opowiadania o ziołach i zwierzętach, s. 57. Zob. również: Kompendium wiedzy o ekologii, red. J. Strzałko, T. Mossor-Pietraszewska, Warszawa-Poznań 2001, s. 292-310.

44 Tamże, s. 25.

45 Tamże, s. 244. 
wiekowi” ${ }^{46}$. W przeciwieństwie do zwierząt towarzyszących, "czyli takich, które są dla danej osoby obiektem znaczącym i z którym łączy go bliska więź" ${ }^{47}$, rośliny towarzyszące, według Kossak, zostały w pewnym momencie odrzucone przez człowieka. Przykład stanowi Babka wąskolistna, która „W nagrodę za tak wierną służbę doczekała się miana chwastu i chemicznego tępienia. I znów, jak trzy tysiące lat temu, znalazła się w dostojnym towarzystwie - dziś do chwastów zaliczono większość najcudowniejszych ziół" ${ }^{\prime 4}$. Michał Książek, komentując interesujące Kossak miejsca występowania roślin, dochodzi do wniosku, że w opowiadaniach badaczki „chodzi o podróż do tutaj, jeszcze nie do zupełnego «tam», o podróż w bliż: nasyp kolejowy, pole za oknem, skwer z drzewem, jeśli jeszcze nie wycięli" ${ }^{49}$. Istotnym elementem Opowiadan o ziołach $i$ zwierzętach jest fakt, że wyrastają one z konkretnego miejsca, Puszczy Białowieskiej. „Bory białowieskie - ciemne, pachnące igliwiem, a na ich dnie niepozorna krzewinka tworząca rozległe łany” 50; „Potężny Król Jagiełło [dąb - dop. K.T.] z Puszczy Białowieskiej padł obalony jesienną wichurą w 1974 roku” 51 ; "Największe skupiska okazałych jesionów zachowały się w [...] Sommerset w Anglii, a na kontynencie w Maklemburgii, w Rosji i u nas w Puszczy Białowieskiej" 52. Puszcza Białowieska jest środowiskiem większości opisanych przez Kossak roślin, z czego wynika, że wybrała je nieprzypadkowo i wiążą się one $z$ doświadczeniem najbliższej dla niej, lokalnej przyrody.

\section{Imię}

O stosunku człowieka do roślin często świadczą nadawane im nazwy. Kossak konsekwentnie mówi jednak nie o nazwach, lecz o „imionach”. „Są rośliny obdarzone tylko jednym imieniem. Są i takie, które noszą wiele różnych nazw. Tatarak, tatarczuch, kalmus, łącz, szczwar, tatarskie ziele, łabudź i pochodzące wprost z Azji - ajer. Ktoś też, nie wiedzieć czemu, obraził

\footnotetext{
46 Tamże, s. 303.

47 B. Mirucka, U. Bielecka, Intrapsychiczne i interpersonalne funkcje relacji człowieka ze zwierzęciem towarzyszacym, „Psychologia Społeczna” 2014, t. 9, nr 3, s. 338.

48 S. Kossak, Opowiadania o ziołach i zwierzętach, s. 10.

49 M. Książek, Podróż do tutaj, https://www.dwutygodnik.com/artykul/7071-podroz-do-tu taj.html [dostęp 16.01.2017].

50 S. Kossak, Opowiadania o ziołach i zwierzętach, s. 17.

51 Tamże, s. 65.

52 Tamże, s. 129.
} 
tę piękną, wyniosłą i pożyteczną bylinę, zwąc ją wielkim gałganem" 53. Halina Pelcowa w artykule Nazwy roślin w świadomości językowej ludności wiejskiej stwierdza:

mechanizmy funkcjonowania nazw w gwarach i skojarzenia towarzyszące nominacjom roślin na co dzień, zawarte [są - K.T.] w potocznym [...] obrazie świata, uwarunkowane przy tym kulturowo, religijnie, społecznie, geograficznie [...]. W opowiadaniach o roślinach przejawia się zarówno obyczajowość ludowa, kulturotwórcza funkcja świata roślinnego, jak i postrzeganie nazw roślin jako sposobu wartościowania świata dawnego i współczesnego ${ }^{54}$.

Simona Kossak w Opowiadaniach o ziołach $i$ zwierzętach często przywołuje źródłosłów roślinnych nazw. Skrzyp polny, jak zauważa, zawdzięcza swoje imię dźwiękom wydawanym przez niego w trakcie pocierania w dłoni. Z kolei Szałwia lekarska otrzymała imię dzięki właściwościom leczniczym: "Jej imię Salvia jedni wywodzą od salvus - zdrowy, inni od salvoere - ratować, leczyć" 55. Bywa jednak, że nazwa rośliny nie odnosi się do jej historii czy właściwości: „Pochopnie twierdzi się, że tatarak został zawleczony przez Tatarów - czego ma dowodzić jego nazwa. Jest w tym tylko część prawdy" ${ }^{56}$. Michał Książek zauważa:

gatunek, nazwa gatunkowa, to także sposób na przestrzeń. Na jej anonimowość. Wiemy przecie, że siedmiopalecznika błotnego spodziewać się trzeba na błotach. Turzycy brzegowej na brzegach. Jasieńca piaskowego na piaskach. Świerzbnicy polnej. Skrzypu łąkowego. Czyśćca leśnego. Okrężnicy bagiennej. Pieprzycznika przydrożnego ${ }^{57}$.

Nazwy roślin świadczyć mogą bądź o miejscu ich występowania, bądź o magicznych właściwościach. Warto jednak raz jeszcze podkreślić, że Simona Kossak w odniesieniu do roślin konsekwentnie mówi o imieniu, nie nazwie, przez co w pewnym sensie upodmiotawia je.

Opowiadania o ziołach $i$ zwierzętach Simony Kossak warto poddać refleksji ekokrytycznej, która podczas kilkudziesięciu lat swojego rozwoju wypracowała narzędzia do badania tekstów literackich. Przykładem jest pro-

53 Tamże, s. 320.

54 H. Pelcowa, Nazwy roślin w świadomości językowej ludności wiejskiej, „Acta Universitatis Wratislaviensis” 2001, nr 2282, "Język a kultura”, t. 16, Świat roślin w języku i kulturze, s. 99.

55 S. Kossak, Opowiadania o ziołach i zwierzętach, s. 303.

56 Tamże, s. 323.

57 M. Książek, Podróż do tutaj, https://www.dwutygodnik.com/artykul/7071-podroz-do-tu taj.html [dostęp 16.01.2017]. 
pozycja rozważenia dzieła literackiego jako environmental text, tekst środowiskowy. Termin zaproponowany został przez jednego z czołowych badaczy pierwszej fali ekokrytyki, Lawrence'a Buella ${ }^{58}$. Aleksandra Ubertowska w artykule "Mówić w imieniu biotycznej wspólnoty". Anatomie i teorie tekstu środowiskowego/ekologicznego analizuje propozycję, prezentując w ośmiu punktach podstawowe wyznaczniki tekstu środowiskowego ${ }^{59}$. Według założeń takiego tekstu natura nie może być tłem, lecz centrum wypowiedzi. Istotną rolę odgrywa również świadomość autora, przekonanego o fakcie, że ludzka historia generowana jest przez historię naturalną oraz jego poczucie odpowiedzialności za stan środowiska naturalnego. Kolejnym wymogiem tekstu środowiskowego jest kreacja oryginalnego, całościowego świata, w którym związek człowieka z przestrzenią może być określany mianem bioregionalizmu. Autor tekstu środowiskowego zawsze aktualizuje jakiś chronotop, na przykład rytm pór roku. W tego typu narracji redefinicji podlega idea podmiotu, który staje się jednym z elementów sieci zależności. Ubertowska zauważa, że w przypadku omawianego przez nią environmental text następuje widoczne odejście od jednych gatunków literackich na rzecz drugich. Istotniejszą rolę odgrywają te, w których występuje zainteresowanie i odpowiedzialność za strefę przedmiotową opisu. Powieść psychologiczna czy literatura ego-centryczna nie stanowi w tym wypadku obiektu zainteresowania ekokrytyki. Sposób prowadzenia narracji również odgrywa istotną rolę, uprzywilejowując teksty, które próbują oddać nielinearność życia za pośrednictwem nielinearnych narracji, co faworyzuje mikroeseje, nieciągłe sekwencje czy kontemplacje natury. Opowiadania o ziotach $i$ zwierzętach Simony Kossak w większym lub mniejszym stopniu realizują podstawowe założenia tak rozumianego tekstu środowiskowego. Pomimo, że chronotop nie odgrywa w przypadku omawianego tu zbioru narracji przyrodniczych dużej roli, to jednak $\mathrm{w}$ innych tekstach Kossak pełni niezwykle istotną funkcję. Przykład stanowią gawędy rejestrowane w naturalnych plenerach Puszczy Białowieskiej, we wszystkich porach roku. Gawędy te zostały opublikowane $\mathrm{w}$ kilku tomach już po śmierci autorki, a każdy zbiór nosi nazwę związaną z konkretnymi przestrzeniami występowania roślin i zwierząt: Powietrze, Woda, Ziemia ${ }^{60}$.

58 Zob. L. Buell, The environmental Imagination. Thoreau, Nature, Writing, and the Formation of American Culture, London 1995.

59 Zob. A. Ubertowska, "Mówić w imieniu biotycznej wspólnoty”. Anatomie i teorie tekstu środowiskowego/ekologicznego, "Teksty Drugie” 2018, nr 2, s. 17-39.

60 S. Kossak, Powietrze, Białystok 2011; S. Kossak, Woda, Białystok 2011; S. Kossak, Ziemia, Białystok 2011. 
Opowiadania o ziołach i zwierzętach. Zgodnie z natura swojego gatunku wpisują się również w założenia projektu historii ratowniczej, o której Ewa Domańska pisze:

ten rodzaj historii zaangażowanej ma także często charakter transformujący podmiotowość - wpływa na „podnoszenie świadomości” i zmienia stosunek ludzi do ludzi, natury, zwierząt, roślin, a także rzeczy. Zachęca ponadto, by widzieć procesy zachodzące $\mathrm{w}$ świecie nie tylko $\mathrm{w}$ kategoriach cyklów ekonomicznych, społecznych czy politycznych, lecz także biologicznych; by mówić o systemach społecznych, ale też o ekosystemach. Historia ratownicza staje się przez to elementem humanistyki restytutywnej - humanistyki odbudowy; humanistyki regeneracyjnej, wspierającej, afirmatywnej ${ }^{61}$.

Simona Kossak swoją działalnością popularyzatorską przyczyniła się do uwrażliwiania odbiorców na przyrodę oraz zaszczepienia $w$ nich idei jej ochrony. Walczyła $\mathrm{w}$ sprawie ochrony roślin i zwierząt $\mathrm{w}$ drugiej połowie lat dziewięćdziesiątych oraz na początku XXI wieku, kiedy organizacje ekologiczne $\mathrm{w}$ Polsce dopiero zaczynały się formować, lecz nie miały jeszcze dużego zrozumienia w społeczeństwie. Uważam, że działalność piśmiennicza Simony Kossak to próba napisania herbstory, której założenia są zbieżne z założeniami historii ratowniczej, zorientowanej na ratowanie przyszłości. Simona Kossak w 1995 roku poruszyła temat, który ówczesnej Polsce był obcy, a na zachodzie dopiero zaczął się kształtować. Chodzi o kwestię podmiotowości roślin, ich sprawczość i bezpośredni wpływ na historię. Badaczka-pisarka postanowiła oddać głos tym podmiotom, które dotychczas były wykluczone z oficjalnej narracji. Poświęciła uwagę zarówno roślinom, takim jak Dąb czy Lipa, które w skali hierarchii wartości stoją wyżej niż na przykład Cykoria podróżnik, Dziurawiec czy Krwawnik. Jednak to tym ostatnim autorka przygląda się z ogromną dozą empatii, a za pośrednictwem swoich opowiadań chce przywrócić właśnie ziołom i ich historiom należne im miejsce.

\section{Bibliografia}

Barcz Anna (2016), Zagadnienia i problemy badawcze ekokrytyki, w: A. Barcz, Realizm ekologiczny. Od ekokrytyki do zookrytyki w literaturze polskiej, Katowice: „Śląsk" Wydawnictwo Naukowe, s. 19-51.

Borovich Miriam (2017), Rośliny nas ocala: 15 roślin leczniczych, zdolnych puścić z torbami koncerny farmaceutyczne, przeł. K. Majkowska, Warszawa: Muza.

61 E. Domańska, Historia ratownicza, s. 13. 
Buell Lawrence (1995), The environmental Imagination. Thoreau, Nature, Writing, and the Formation of American Culture, London: The Belknap Press.

Domańska Ewa (2014), Historia ratownicza, „Teksty Drugie”, nr 5, s. 12-26.

Domańska Ewa (2013), Humanistyka ekologiczna, „Teksty Drugie”, nr 1-2, s. 13-32.

Domańska Ewa (2017), Nekros. Wprowadzenie do ontologii martwego ciała, Warszawa: Wydawnictwo Naukowe PWN.

Dyakowski Bohdan (1898), Nasz las i jego mieszkańcy: dla młodzieży, Warszawa: M. Arct. Dyakowski Bohdan (1928), Wąż Władka: opowiadanie, Warszawa: M. Arct.

Dyakowski Bohdan (1903), Z naszej przyrody: obrazy z życia roślin i zwierząt krajowych, Warszawa: M. Arct.

Dyakowski Bohdan (1908), Z puszczy Białowieskiej, Warszawa: Redakcya „Przyjaciela Dzieci".

Harrison Christina, Gardiner Lauren (2018), Zdumiewające zdolności roślin, przeł. A. Kowalska, A. Jankowski, Warszawa: Amber.

Kania Eliza (2011), Polska zdekolonizowana? „Pamięć o kobietach" i jej wymiary, „Refleksje", nr 4, s. 51-61.

Kossak Simona (2017), O ziołach i zwierzętach, Warszawa: Wydawnictwo Marginesy.

Kossak Simona (1995), Opowiadania o ziołach i zwierzętach. Zgodnie z natura swojego gatunku, Warszawa: Wydawnictwo Alfa.

Kossak Simona (2017), Opowieści z Dziedzinki, Białystok: Fundacja Sąsiedzi.

Kossak Simona (2011), Powietrze, Białystok: Regionalna Dyrekcja Ochrony Środowiska w Białymstoku.

Kossak Simona (2001), Saga Puszczy Białowieskiej, Warszawa: Muza.

Kossak Simona (2016), Saga Puszczy Białowieskiej, Warszawa: Wydawnictwo Marginesy.

Kossak Simona (2016), Opowieści, Białystok: Fundacja Sąsiedzi.

Kossak Simona (2011), Woda, Białystok: Regionalna Dyrekcja Ochrony Środowiska w Białymstoku.

Kossak Simona (2011), Ziemia, Białystok: Regionalna Dyrekcja Ochrony Środowiska w Białymstoku.

Książek Michał (2015), Droga 816, Białystok: Fundacja Sąsiedzi.

Książek Michał (2017), Podróż do tutaj, https://www.dwutygodnik.com/artykul/7071 -podroz-do-tutaj.html.

Kuleczka Pola (2000), Bohdan Dyakowski. Monografia literackiej twórczości popularyzatora wiedzy o przyrodzie, Kraków: „Secesja”.

Laws Bill (2016), 50 roślin, które zmieniły bieg historii, przeł. J.J. Malinowski, Warszawa: Oficyna Wydawnicza Alma-Press.

Mancuso Stefano (2018), Rewolucyjny geniusz roślin. Jak i dlaczego rośliny zmienią nasza przyszłość, przeł. A. Wziątek, Wrocław: Bukowy Las.

Mirucka Beata, Bielecka Urszula (2014), Intrapsychiczne i interpersonalne funkcje relacji człowieka ze zwierzęciem towarzyszącym, "Psychologia Społeczna”, t. 9, nr 3, s. 338-346.

Nowakowska Aleksandra (2018), Rośliny nas uleczą: dieta na superodporność $i$ długie życie, Opypy: „Edycja” Anna Magdziarz. 
Owczarek Bogdan (2001), Od poetyki do antropologii opowiadania, w: Praktyki opowiadania, red. B. Owczarek, Z. Mitosek, W. Grajewski, Kraków: Universitas, s. 11-21. Pelcowa Halina (2001), Nazwy roślin w świadomości językowej ludności wiejskiej, „Acta Universitatis Wratislaviensis" 2001, nr 2282, „Język a kultura”, t. 16, Świat roślin w języku i kulturze, s. 99-116.

Stewart Amy (2011), Zbrodnie roślin: chwast, który zabił matkę Abrahama Lincolna i inne botaniczne okropieństwa, przeł. D. Wójtowicz, Warszawa: Wydawnictwo W.A.B.

Strzałko Jan, Mossor-Pietraszewska Teresa [red.] (2001), Kompendium wiedzy o ekologii, Warszawa-Poznań: Wydawnictwo Naukowe PWN.

Trusewicz Katarzyna (2016), Ekogawędy Simony Kossak, „Białostockie Studia Literaturoznawcze", nr 9, s. 95-105.

Ubertowska Aleksandra (2018), „Mówić w imieniu biotycznej wspólnoty”. Anatomie i teorie tekstu środowiskowego/ekologicznego, "Teksty Drugie", nr 2, s. 17-39.

Żelazińska Aleksandra (2017), Litenatura, „Polityka”, nr 10, s. 84-86.

\section{Herbstory/Herstory: Simony Kossak's Way}

\section{Summary}

Drawing from the analogous "herstory", the article uses the term "herbstory" to read Simona Kossak's book of herbs Opowiadania o ziołach $i$ zwierzętach. Zgodnie z natura swojego gatunku. The nature narratives are analyzed as examples of "rescue history" and environmental writing.

Keywords: ecology, ecocriticism, herbs, nature, environmental text 